\title{
The influence of economic factors in the management of health and safety specific to SMEs
}

\author{
Gabriela Caldarescu ${ }^{1}$, George Daniel Tanasievici ${ }^{1}$, Costica Bejinariu ${ }^{2}$, and Mihai-Adrian \\ Bernevig $^{2 *}$ \\ ${ }^{1}$ Labor Inspectorate Iasi, Fire Mill Road, no. 31, 707410 Iasi, Romania \\ 2"'Gheorghe Asachi" Technical University of Iasi, D. Mangeron Blv., no. 67, 700050 Iasi, Romania
}

\begin{abstract}
The first of the general objectives of the National Strategy in the field of health and safety at work for the period 2018 - 2020 in Romania was "a better implementation of the choice of occupational safety and health legislation, especially in micro-enterprises and SMEs".In this context, this paper presents the main vulnerabilities of management in SMEs, where the occupational safety and health component has a formal role being strongly influenced by economic factors. The first part presents a statistical situation of the verification campaigns, carried out in the last 3 years by Labor Inspection, on how SMEs have implemented health and safety legislation in their activities, subsequently, an analysis is made of the economic factors that have limited the development of health and safety management. Finally, a cost-benefit analysis is presented on the economic consequences that occur in the event of an accident and / or illness that demonstrates the theory that economic factors influence the management of health and safety and health specific to SMEs both before and after an event occurs.
\end{abstract}

\section{Introduction}

According to the European Commission's Annual SME Report for 2017/2018, SMEs account for $99 \%$ of businesses operating in the EU's non-financial enterprises sector, $66 \%$ of total jobs and $57 \%$ of value added in the EU non-financial enterprises sector [1].

In order to stimulate the creation of a safe and healthy working environment in SMEs, an important factor in occupational safety and health strategies is compliance with legal obligations and enforcement measures taken by control bodies, which remain key factors for the management of OSH [2]. By studying the activity reports of the Romanian Labor Inspection over the past three years, we identify a concern for the control and monitoring of jobs in micro-enterprises, small and medium-sized enterprises with two main objectives: awareness of employers about the need to comply with legal requirements in the field of safety and health at work and identification of the situation of prevention and protection activities carried out within SMEs [1,3].

\footnotetext{
${ }^{*}$ Corresponding author: mihaibernevig@gmail.com
} 


\section{Motivation}

In the years 2018 and 2019, two monitoring actions on risks in micro and medium-sized enterprises in three stages were carried out at national level as part of specific campaigns in the field of safety and health at work: the self-assessment stage of micro and medium-sized enterprises on the basis of a questionnaire, the self-assessment analysis phase and the verification stage. numbers.

Table 1. Statistical situation at national level $[4,5]$.

\begin{tabular}{|c|c|c|}
\hline \multicolumn{3}{|c|}{$\mathbf{2 0 1 8}$} \\
\hline $\begin{array}{c}\text { Number of medium- } \\
\text { which distributed } \\
\text { questionnaires }\end{array}$ & $\begin{array}{c}\text { Number of medium-sized } \\
\text { enterprises which } \\
\text { submitted complete } \\
\text { questionnaires }\end{array}$ & $\begin{array}{c}\text { Total number of } \\
\text { workers who } \\
\text { responded to } \\
\text { questionnaires }\end{array}$ \\
\hline 3862 & 2284 & 216120 \\
\hline \multicolumn{3}{|c|}{$\mathbf{2 0 1 9}$} \\
\hline $\begin{array}{c}\text { Number of micro- } \\
\text { enterprises which } \\
\text { distributed } \\
\text { questionnaires }\end{array}$ & $\begin{array}{c}\text { Number of micro- } \\
\text { enterprises which } \\
\text { submitted complete } \\
\text { questionnaires }\end{array}$ & $\begin{array}{c}\text { Total number of } \\
\text { workers who } \\
\text { responded to } \\
\text { questionnaires }\end{array}$ \\
\hline 7382 & 6634 & 57595 \\
\hline
\end{tabular}

Table 2. Statistical situation at Iasi County level $[4,5]$.

\begin{tabular}{|c|c|c|}
\hline \multicolumn{3}{|c|}{$\mathbf{2 0 1 8}$} \\
\hline $\begin{array}{c}\text { Number of medium- } \\
\text { sized enterprises } \\
\text { which distributed } \\
\text { questionnaires }\end{array}$ & $\begin{array}{c}\text { Number of medium-sized } \\
\text { enterprises which } \\
\text { submitted complete } \\
\text { questionnaires }\end{array}$ & $\begin{array}{c}\text { Total number of } \\
\text { workers who } \\
\text { responded to } \\
\text { questionnaires }\end{array}$ \\
\hline 144 & 127 & 16120 \\
\hline \multicolumn{3}{|c|}{$\mathbf{2 0 1 9}$} \\
$\begin{array}{c}\text { Number of micro- } \\
\text { enterprises which } \\
\text { distributed } \\
\text { questionnaires }\end{array}$ & $\begin{array}{c}\text { Number of micro- } \\
\text { enterprises which } \\
\text { submitted complete } \\
\text { questionnaires }\end{array}$ & $\begin{array}{c}\text { Total number of } \\
\text { workers who } \\
\text { responded to } \\
\text { questionnaires }\end{array}$ \\
\hline 241 & 175 & 1032 \\
\hline
\end{tabular}

At Iasi county level, it was possible to analyze the responses provided by employers and the findings of labor inspectors as a result of the field checks resulting in a set of contradictory information in the sense that:

- all 127 employers in medium-sized enterprises (in 2018) and 175 in micro-enterprises (in 2019) responded positively, in various ways, with a high percentage of calling for external prevention and protection services (85 responses in 2018 and 164 in 2019) to the questions: "Has the organizational framework necessary for prevention and protection work been provided?", "Are emergency routes and exits kept at all times free to allow workers to be evacuated as quickly and as safely as possible?", "Is regular monitoring of workers health ensured by an occupational health doctor?", "Is occupational safety and health signs ensured where necessary?", "Where risks could not be avoided or sufficiently limited, is the individual protective equipment suitable for the work carried out and the individual characteristics of the workers ensured?";

- 126 employers in medium-sized enterprises (in 2018) and 169 in micro-enterprises (in 2019) responded positively to the questions: "Have the risks to the safety and health of workers been assessed?" and "Following the risk assessment, has the prevention and protection plan been drawn up?"; 
- 122 employers in medium-sized enterprises (in 2018) and 170 in micro-enterprises (in 2019) have responded positively to the question: "Are workers and/or their representatives consulted and participating in the discussion of issues relating to safety and health at work?".

Table 3. Situation results action - controls at the level of Iasi county [4, 5].

\begin{tabular}{|c|c|c|}
\hline \multirow{4}{*}{$\begin{array}{c}\text { YEAR } \\
\mathbf{2 0 1 8}\end{array}$} & $\begin{array}{c}\text { Total number of medium- } \\
\text { sized enterprises (MIs) } \\
\text { controlled }\end{array}$ & 61 \\
\cline { 2 - 3 } & $\begin{array}{c}\text { Number of measures ordered } \\
\text { as a result of the checks }\end{array}$ & 98 \\
\cline { 2 - 3 } & $\begin{array}{c}\text { Number of sanctioned } \\
\text { medium-sized enterprises }\end{array}$ & 61 \\
\hline \multirow{2}{*}{$\begin{array}{c}\text { YeAR } \\
\mathbf{2 0 1 9}\end{array}$} & $\begin{array}{c}\text { Total number of controlled } \\
\text { micro-enterprises (MI) }\end{array}$ & 91 \\
\cline { 2 - 3 } & $\begin{array}{c}\text { Number of measures ordered } \\
\text { as a result of the checks }\end{array}$ & 223 \\
\cline { 2 - 3 } & $\begin{array}{c}\text { Number of micro-enterprises } \\
\text { sanctioned }\end{array}$ & 88 \\
\hline
\end{tabular}

Subsequently, following the checks carried out on the 61 medium-sized enterprises (in 2018) and 91 micro-enterprises (in 2019) which submitted the questionnaires, it was found that the percentage of those who did not comply with the security requirements is higher than that declared and more pronounced in micro-enterprises, which led to the identification of a number of non-conformities (Table 3 ), and in this respect we exemplify:

- 4 employers in medium-sized enterprises (in 2018) and 23 in micro-enterprises (in 2019) do not comply with the requirement of: "Is occupational safety and health signs ensured where necessary?";

- 12 employers in micro-enterprises (in 2019) do not comply with the requirement of: "Is regular supervision of workers health ensured by occupational medicine doctor?";

- 16 employers in medium-sized enterprises (in 2018) and 7 in micro-enterprises (in 2019) do not comply with the requirement of: "Are emergency routes and exits kept at all times free to allow the rapid and safe evacuation of workers?";

- 4 employers in medium-sized enterprises (in 2018) and 17 in micro-enterprises (in 2019) do not comply with the requirement of: "Is work equipment accompanied by technical books or instructions for use and maintenance?";

- 9 employers in medium-sized enterprises (in 2018) and 7 in micro-enterprises (in 2019) do not comply with the requirement of: "Are workers and/or their representatives consulted and participate in the discussion of issues relating to safety and health at work?".

By comparison, from a statistical point of view it is found that at national level the percentage of those which do not comply with the higher security requirements in microenterprises than in medium-sized enterprises, but the number of measures ordered is inversely proportional:

Table 4. National control situation $[1,3]$.

\begin{tabular}{|c|c|c|}
\hline \multirow{2}{*}{$\begin{array}{c}\text { YEAR } \\
\mathbf{2 0 1 8}\end{array}$} & $\begin{array}{c}\text { Total number of medium- } \\
\text { sized enterprises (MIs) } \\
\text { controlled }\end{array}$ & 2284 \\
\cline { 2 - 3 } & $\begin{array}{c}\text { Number of measures } \\
\text { ordered as a result of the } \\
\text { checks }\end{array}$ & 4904 \\
\cline { 2 - 3 } & $\begin{array}{c}\text { Number of sanctioned } \\
\text { medium-sized enterprises }\end{array}$ & 1814 \\
\hline
\end{tabular}




\begin{tabular}{|c|c|c|}
\hline \multirow{2}{*}{$\begin{array}{c}\text { YEAR } \\
\text { 2019 }\end{array}$} & $\begin{array}{c}\text { Total number of controlled } \\
\text { micro-enterprises (MI) }\end{array}$ & 4073 \\
\cline { 2 - 3 } & $\begin{array}{c}\text { Number of measures } \\
\text { ordered as a result of the } \\
\text { checks }\end{array}$ & 5464 \\
\cline { 2 - 3 } & $\begin{array}{c}\text { Number of micro- } \\
\text { enterprises sanctioned }\end{array}$ & 2944 \\
\hline
\end{tabular}

\section{Influence of economic factors in the development of SMEs}

The activity of SMEs can be influenced by a number of factors that appear in the literature grouped into economic, technical and technological factors, management, policies, sociocultural, legal, demographic etc. In view of the multitude of factors, in this paper we will focus on the economic factors that limit the development of SMEs and implicitly the management of occupational safety and health, namely: the financial potential of the economy, the pace of economic development of the country, the economic - financial levers, the unemployment rate, the interest rate, the dimensions and forms of manifestation of the underground economy; the mechanism for price formation; the system of taxes and charges; economic stability, the internal and international market [6]. For SMEs, survival and development depend on the market and other economic factors (prices, loans, taxes, taxes etc.) contribute to the size of the profit and the way of distribution.

In this context, although each category of factor influences activities specifically, when we talk about the field of safety and health, we can say that SMEs use competent external services regardless of their size and financial capacity in order to solve a legislative problem and not to mitigate the risks of injury in the workplace. Given the frequency of injuries and deaths provided by statistics, jobs appear to be considerably more dangerous in small companies than in large companies [7-9].

Also, at EU level, injuries that cause incapacity for work occur at $82 \%$ in economic activities in SMEs and 90\% in deaths $[2,10]$.

Looking at these statistics and strategies we can say that the management of safety and health in SMEs is deficient although it should be an essential component in the prevention system for reducing accidents at work and ensuring safety and health at work in the economic activities carried out.

\section{Economic consequences at SME level in the event of accidents at work}

The Labor Inspection Activity Report 2019 shows that 4332 workers who suffered accidents at work and 233162 days of incapacity for work were registered nationwide in 2019.

Table 5. Situation of injuries with temporary incapacity for work completed in 2018 - Indices of gravity and average duration [3].

\begin{tabular}{|c|c|c|c|c|c|c|c|c|}
\hline & 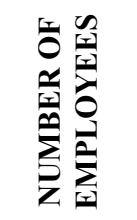 & 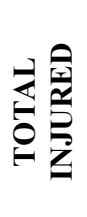 & 忞 & 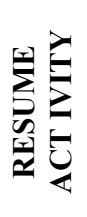 & 氞 & 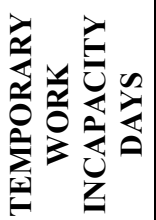 & 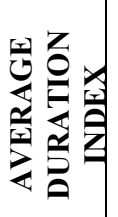 & 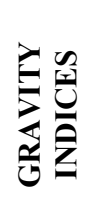 \\
\hline $\begin{array}{c}\text { TOTAL } \\
\text { ECONOMY }\end{array}$ & 5331301 & 4341 & 80 & 4226 & 35 & 229557 & 52.88 & 43.06 \\
\hline
\end{tabular}


Table 6. Situation of injuries with temporary incapacity for work completed in 2019 - Indices of gravity and average duration [1].

\begin{tabular}{|c|c|c|c|c|c|c|c|c|}
\hline & 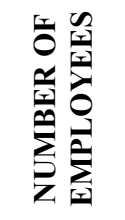 & 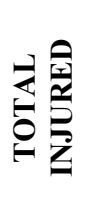 & 帘 & 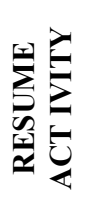 & 矛 & 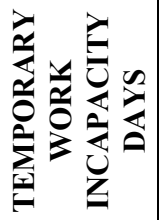 & 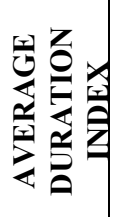 & 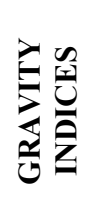 \\
\hline $\begin{array}{c}\text { TOTAL } \\
\text { ECONOMY }\end{array}$ & 5425931 & 4332 & 80 & 4222 & 30 & 233162 & 53.82 & 42.97 \\
\hline
\end{tabular}

Based on the statistical data described above we can issue the following working hypotheses:

1. if $82 \%$ of accidents with temporary incapacity for work and $90 \%$ of fatal accidents are due to economic activities in SMEs, then in 2019 the total number of 4332 victims shows that about 3489 are workers who have suffered accidents;

2. if 4332 victims have about 233162 days of temporary incapacity for work, an average of 3489 of about 187789 days of temporary incapacity for work results;

3. if in 2019 about 500000 SMEs in Romania were injured 3489 workers and there were registered about 187789 days with temporary incapacity for work then by approximation, we can say that 143 SMEs are injured a worker and an SME reports 2.66 days of temporary incapacity for work.

In parallel, in order to be able to discuss the hypotheses made, we present a cost calculation simulation for an employee in two distinct situations, when he is at work and when he is temporarily incapacitated as a result of an accident at work.

Table 7. Simulated salary calculation.

\begin{tabular}{|l|c|c|}
\hline Gross salary & & $\mathbf{3 0 0 0}$ RON \\
\hline Social Insurance & $25 \%$ & $750 \mathrm{RON}$ \\
\hline Social Health Insurance & $10 \%$ & $300 \mathrm{RON}$ \\
\hline Personal deduction & & $195 \mathrm{RON}$ \\
\hline Income tax & $10 \%$ & $176 \mathrm{RON}$ \\
\hline Net Salary & & $\mathbf{1 7 7 4} \mathbf{R O N}$ \\
\hline Insurance contribution for Work & $2.25 \%$ & 68 RON \\
\hline Total salary contributions & & 1489 RON \\
\hline Full salary & & $\mathbf{3 0 6 8} \mathbf{R O N}$ \\
\hline
\end{tabular}

A simulation of the calculation of sick leave in the event of an accident at work, in relation to a month by 20 working days, shows that:

Table 8. Simulated calculation sick leave paid $100 \%$ for 20 working days.

\begin{tabular}{c|c}
$\begin{array}{c}\text { Daily average for 100\% paid sick } \\
\text { leave }\end{array}$ & $\begin{array}{c}3000 \times 6 \text { Months }=18000 / 120 \\
\text { working days }=150 \mathrm{RON} / \text { Day } \\
* 100 \%\end{array}$ \\
\hline
\end{tabular}




\begin{tabular}{|c|c|}
\hline $\begin{array}{c}\text { 3 days paid from the Salary Fund - } \\
\text { employer }\end{array}$ & 450 RON \\
\hline $\begin{array}{c}\text { 17 days paid from the National } \\
\text { Single Health Insurance Fund }\end{array}$ & 2550 RON \\
\hline
\end{tabular}

Table 9. Simulated calculation sick leave paid $80 \%$ for 20 working days.

\begin{tabular}{|c|c|}
\hline $\begin{array}{c}\text { Daily average for 80\% paid sick } \\
\text { leave }\end{array}$ & $\begin{array}{c}3000 \times 6 \text { Months }=18000 / 120 \\
\text { working days }=150 \mathrm{RON} / \text { Day } \\
* 80 \%=120 \mathrm{RON} / \mathrm{Day}\end{array}$ \\
\hline $\begin{array}{c}\text { 3 days paid from the Salary Fund - } \\
\text { employer }\end{array}$ & $360 \mathrm{RON}$ \\
\hline $\begin{array}{c}\text { 17 days paid from the National } \\
\text { Single Health Insurance Fund }\end{array}$ & $2040 \mathrm{RON}$ \\
\hline
\end{tabular}

In conclusion, the costs of sick leave for a worker who has a gross salary of 3000 RON are $150 \mathrm{RON} /$ day when he is paid $100 \%$ and $120 \mathrm{RON}$ when he is paid $80 \%$.

Therefore, if an SME has 2.66 days of incapacity for work, then the costs of sick leave can be 399 RON and 319.2 RON respectively compared to a calendar year.

The estimated minimum necessary costs for an SME to ensure the safety and health at work for a person in employment by resorting to competent external services is:

Table 10. Estimated minimum costs to ensure the safety and health at work for a person in employment by resorting to competent external services.

\begin{tabular}{|c|c|c|}
\hline Cost Type & price in RON & $\begin{array}{c}\text { Total in } \\
\text { RON }\end{array}$ \\
\hline $\begin{array}{c}\text { Minimum costs of employment } \\
\text { training }\end{array}$ & $\begin{array}{c}35 \text { RON/person } \\
\text { /2 trainings }\end{array}$ & 70 \\
\hline Medical check-up costs & 30 RON/person & 30 \\
\hline $\begin{array}{c}\text { Minimum costs of individual } \\
\text { protective equipment of which: }\end{array}$ & 120 & \\
\hline Overalls & 80 & \\
\hline Headset & 120 & \\
\hline Protective footwear & 35 & 355 \\
\hline Gloves & & $\mathbf{4 5 5}$ \\
\hline Total & & \\
\hline
\end{tabular}

Table 11. Estimated minimum costs of an SME to ensure safety and health at work for a person in employment through their own staff.

\begin{tabular}{|c|c|c|}
\hline Cost Type & price in RON & $\begin{array}{c}\text { Total in } \\
\text { RON }\end{array}$ \\
\hline $\begin{array}{c}\text { Minimum training costs }- \\
\text { equivalent to designated worker } \\
\text { wage costs per day }\end{array}$ & 150 RON/day & 150 \\
\hline Medical check-up costs & $30 \mathrm{RON} /$ person & 30 \\
\hline $\begin{array}{c}\text { Minimum costs of individual } \\
\text { protective equipment of which: }\end{array}$ & 120 & \\
\hline Overalls & 120 \\
\hline
\end{tabular}




\begin{tabular}{|c|c|c|}
\hline Headset & 80 & \\
\hline Protective footwear & 120 & \\
\hline Gloves & 35 & 355 \\
\hline Total & & $\mathbf{5 3 5}$ \\
\hline
\end{tabular}

Looking at these calculations we see that an SME invests in the employment of a worker a minimum amount of between 455 and 535 lei to ensure safety and health at work.

Therefore, the amounts that an SME invests in occupational safety and health are small, but comparable to those that statistically revert to the number of injured and the number of days of temporary incapacity for work annually.

To these direct costs, depending on the field of activity, the size of the company and the size of the event, indirect costs arising from the damage to production, the need to carry out repairs or the replacement of machinery and equipment, the damage to the image of the company in the competitive market, etc.. Indirect cost values can be estimated by the ratio of direct costs to indirect costs that may vary, depending on the characteristics of the event and the particularities of the company's activity, from 1:4 to 20:1. Unfortunately indirect costs occur after an event occurs and are not evident in all areas of activity.

\section{Conclusions}

$90 \%$ of SMEs justify the lack of occupational safety and health management by reference to a number of economic factors such as financial problems, very high costs, taxes and charges, staff fluctuation, etc. In fact, as we have seen in the previous calculation the minimum costs of compliance with legal obligations can exceed the costs of an accident at work because in most SMEs there are no accidents (in 2019 there were 3489 victims per 500000 SMEs), which probably means that there are a proportion of more than $50 \%$ of SMEs that have not had and will not have accidents at work.

Against the background of ignorance and due to economic factors SME managers tend to minimize risks in the workplace, to use non-compliant, worn-out personal work equipment and protective equipment, to ensure minimal and formal medical supervision without ensuring continuity in the supervision of the worker's health during the working-profitable life.

SME managers do not give importance to the field, often associate the need to meet legal requirements and related expenses as a necessary cost in order not to take fines and not to keep their workers safe.

Although occupational safety and health management should be a component of the entrepreneurial/investor, it is not found as a concept in the SME literature. This component, which can generate very high, sometimes irreversible, direct and indirect costs (in the event of a fatal accident with criminal implications) is ignored due to the minimal or zero probability of materializing.

In the view of entrepreneurs/investors, the need for knowledge in the field of occupational safety and health becomes a priority after an event has occurred.

Beyond these conclusions that have emerged as a result of the analysis carried out, there is a need for better information and awareness of the consequences of an accident at work from the perspective of prevention, of the legal implications for both the employer and the employee and not finally of the consequences for the victim of an accident at work and his family, effects that can hardly be estimated for both the period of incapacity and psychological implications with effects over time. 


\section{References}

1. Labor Inspection Activity Report for 2019, drawn up on the basis of Conventions 81 and 129 of the International Labor Organization.

2. National Strategy in the field of occupational safety and health for the period 2017-2020.

3. Labor Inspection Activity Report for 2018, drawn up on the basis of Conventions 81 and 129 of the International Labor Organization.

4. Activity report of the Iasi Territorial Labor Inspectorate for 2018.

5. Activity report of the Iasi Territorial Labor Inspectorate for 2019.

6. A. Vocila, The environment of the organization. Available on https://andreivocila.files.wordpress.com/2010/09/cap-2.pdf.

7. J. Mendeloff, C. Nelson, K. Ko, A. Haviland, Small Businesses and Workplace Fatality Risk - An Exploratory Analysis (Rand, 2006) DOI:10.7249/TR371.

8. T. Holizki, R. McDonald, F. Gagnon, Patterns of underlying causes of work-related traumatic fatalities - Comparison between small and larger companies in British Columbia, Saf Sci 71, 197-204 (2015).

9. D. Masi, E. Cagno, Barriers to OHS interventions in Small and Medium-sized Enterprises, Saf Sci 71, 226-241 (2015).

10. European statistics on accidents at work, Eurostat 2014. 